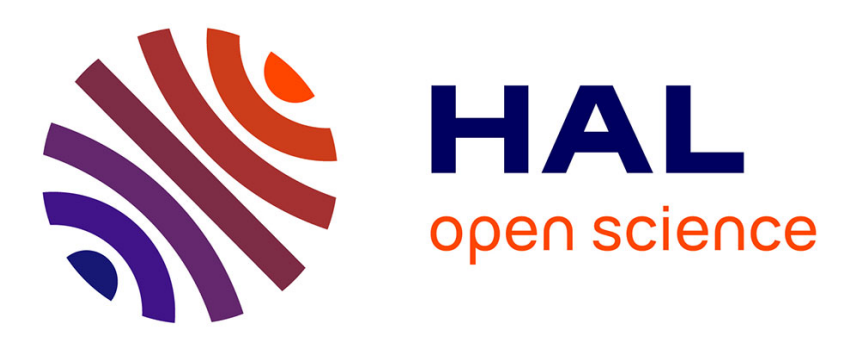

\title{
SHORECASTS: A BLIND-TEST OF SHORELINE MODELS
}

Jennifer Montaño, Giovanni Coco, Jose a A Antolinez, Tom Beuzen, Karin

Bryan, Laura Cagigal, Bruno Castelle, Mark Davidson, Evan Goldstein, Ibaceta Rai, et al.

\section{To cite this version:}

Jennifer Montaño, Giovanni Coco, Jose a A Antolinez, Tom Beuzen, Karin Bryan, et al.. SHORECASTS: A BLIND-TEST OF SHORELINE MODELS. Coastal Sediments'19, May 2019, Tampa, United States. 10.1142/9789811204487_0055 . hal-02394970

\section{HAL Id: hal-02394970 https://hal.science/hal-02394970}

Submitted on 11 Dec 2019

HAL is a multi-disciplinary open access archive for the deposit and dissemination of scientific research documents, whether they are published or not. The documents may come from teaching and research institutions in France or abroad, or from public or private research centers.
L'archive ouverte pluridisciplinaire $\mathbf{H A L}$, est destinée au dépôt et à la diffusion de documents scientifiques de niveau recherche, publiés ou non, émanant des établissements d'enseignement et de recherche français ou étrangers, des laboratoires publics ou privés. 


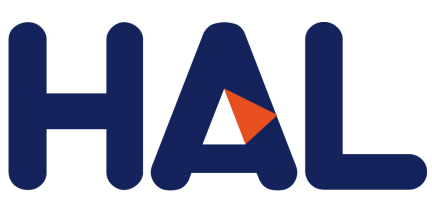

archives-ouvertes

\section{SHORECASTS: A BLIND-TEST OF SHORELINE MODELS}

Rai Ibaceta Vega, Jennifer Montaño, Giovanni Coco, Jose Antolinez, Tom

Beuzen, Karin Bryan, Laura Cagigal, Bruno Castelle, Mark Davidson, Evan

Goldstein, et al.

\section{To cite this version:}

Rai Ibaceta Vega, Jennifer Montaño, Giovanni Coco, Jose Antolinez, Tom Beuzen, et al.. SHORECASTS: A BLIND-TEST OF SHORELINE MODELS. Coastal Sediments'19, May 2019, Tampa, United States. 10.1142/9789811204487_0055 . hal-02394970

\section{HAL Id: hal-02394970 \\ https://hal.archives-ouvertes.fr/hal-02394970}

Submitted on 11 Dec 2019

HAL is a multi-disciplinary open access archive for the deposit and dissemination of scientific research documents, whether they are published or not. The documents may come from teaching and research institutions in France or abroad, or from public or private research centers.
L'archive ouverte pluridisciplinaire HAL, est destinée au dépôt et à la diffusion de documents scientifiques de niveau recherche, publiés ou non, émanant des établissements d'enseignement et de recherche français ou étrangers, des laboratoires publics ou privés. 


\title{
SHORECASTS: A BLIND-TEST OF SHORELINE MODELS
}

\author{
JENNIFER MONTAÑO ${ }^{1}$, GIOVANNI COCO ${ }^{1}$, JOSE A.A. ANTOLINEZ ${ }^{2}$, \\ TOM BEUZEN $^{3}$, KARIN BRYAN $^{4}$, LAURA CAGIGAL ${ }^{1,2}$, BRUNO CASTELLE $^{5}$, \\ MARK DAVIDSON ${ }^{6}$, EVAN GOLDSTEIN $^{7}$, RAI IBACETA VEGA ${ }^{3}$, DEBORAH \\ IDIER $^{8}$, BONNIE LUDKA $^{9}$, SINA MASOUD ANSARI ${ }^{1}$, FERNANDO MENDEZ ${ }^{2}$, \\ BRAD MURRAY ${ }^{10}$, NATHANIEL PLANT ${ }^{11}$, ARTHUR ROBINET $^{5,8}$, ANA RUEDA $^{2}$, \\ NADIA SENECHAL ${ }^{5}$, JOSH SIMMONS ${ }^{3}$, KRISTEN SPLINTER ${ }^{3}$, SCOTT \\ STEPHENS $^{12}$, IAN TOWNEND ${ }^{13}$, SEAN VITOUSEK ${ }^{14,15}$, KILIAN VOS $^{3}$
}

1. School of Environment, Faculty of Science, University of Auckland, Auckland, 1142, New Zealand.jmon177@aucklanduni.ac.nz,g.coco@auckland.ac.nz

2. Surf and surge research group. E.T.S.C.C.P., Universidad de Cantabria, Santander, Spain.

3. Water Research Laboratory, School of Civil and Environmental Engineering, UNSW Sydney, NSW, 2052, Australia.

4. School of Science, University of Waikato, Private Bag 3105, Hamilton, New Zealand

5. UMR EPOC, University of Bordeaux/CNRS, Bordeaux, France.

6. Coastal Processes Research Group, School of Biological and Marine Sciences, Plymouth University, Drake Circus, PL4 8AA Plymouth, UK.

7. Department of Geography, Environment, and Sustainability, University of North Carolina at Greensboro, North Carolina, USA, 27412.

8. BRGM, 3 avenue Claude Guillemin, 45060 Orléans cédex, France.

9. Scripps Institution of Oceanography, University of California, San Diego, United States.

10. Division of Earth and Ocean Sciences, Nicholas School of the Environment, Center for Nonlinear and Complex Systems, Duke University Durham, NC, USA.

11. U.S. Geological Survey St. Petersburg Coastal and Marine Science Center, 600 4th Street South, St. Petersburg, FL, USA.

12. National Institute of Water and Atmosphere, Hamilton, New Zealand.

13. University of Southampton, Southampton SO17 1BJ, UK.

14. Pacific Coastal and Marine Science Center, U.S. Geological Survey Santa Cruz, CA, USA.

15. Department of Civil and Materials Engineering, University of Illinois at Chicago, IL, USA.

\footnotetext{
Abstract: Predictions of shoreline change are of great societal importance, but models tend to be tested and tuned for the specific site of interest. To overcome this issue and test the ability of numerical models to simulate shoreline change over the medium scale (order of years) we have organized a non-competitive competition where participants were given data to train their model (1999-2014) and data to predict seasonal to inter-annual future changes (2014-2017). Participants were shown the observed shoreline changes only after submission of their modelling results. Overall, 19 numerical models were tested, the vast majority falling in the broad categories of "hybrid models" or "machine learning". Models were able to reproduce the mean characteristics of shoreline change but often failed to reproduce the observed rapid changes induced by storms.
} 


\section{Introduction}

Understanding processes regulating beach erosion and recovery remains a fundamental challenge in coastal research due to the inherent uncertainty in predicting the future "drivers" (e.g., wave characteristics) and to our limited understanding of interactions between drivers and response (e.g., sediment transport). Still, given the ongoing climatic changes and that most of the world's population lives near the coast, it is imperative to improve predictive capability of shoreline change. In fact, driven by the pressure from decision-makers, managers, politicians and the public, research efforts to understand and predict shoreline evolution have recently increased.

From a modelling perspective, several approaches have been proposed (Fig. 1), but two approaches seem particularly suited to predict shoreline change over the medium scale (seasonal to inter-annual): (a) Hybrid models (usually based on the equilibrium concept) and (b) machine learning. So far, a number of numerical models have been implemented for the prediction of shoreline evolution but there are very few studies that have attempted a detailed comparison of their predictive skill. The objective of our study is to test the ability of such models in predicting shoreline evolution seasonal to inter-annual scales. Here, we report on a novel approach to prediction and model testing based on a non-competitive competition (Shorecast) and subsequent workshop (Shoreshop 2018) specifically carried to bridge this gap. Overall, contributors from 15 institutions participated to the Shorecast competition and contributed to the discussion on advances in shoreline evolution models.

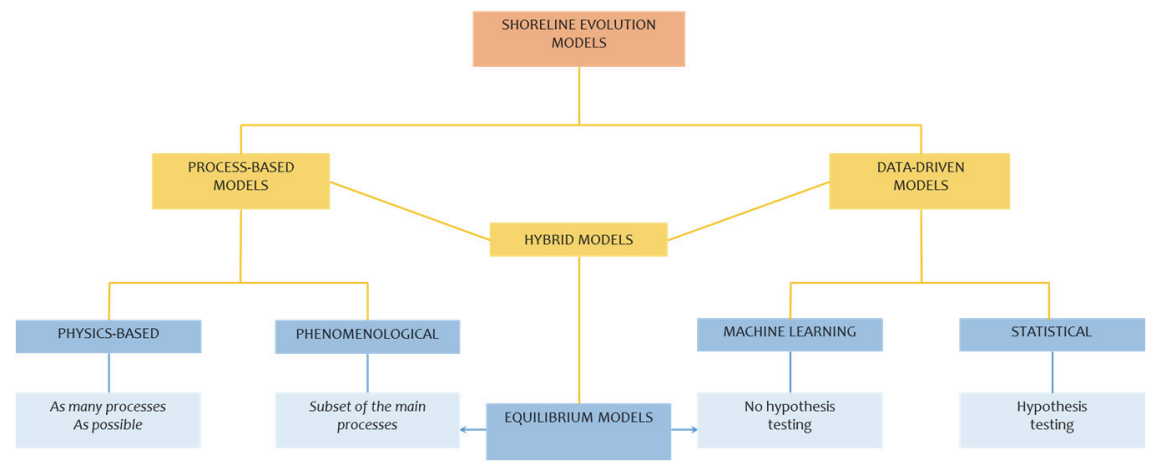

Fig. 1. Classification of numerical models for shoreline change.

\section{Data}

In order to develop the Shorecast competition, data from a variety of sources had to be obtained and compiled. The cornerstone of the dataset is the eighteen years 
(1999-2017) of daily video shoreline position of Tairua Beach (NZ). Tairua Beach (Fig. 2) is an embayed beach of $\sim 1200 \mathrm{~m}$ length located on the Coromandel Peninsula of New Zealand's North Island. Tairua beach faces northeast and is usually exposed to waves characterized by 1-3 m significant height and $10 \mathrm{~s}$ period, and approaching predominantly from NE. The tidal range is around $2 \mathrm{~m}$. The beach is generally steep with sand of mean diameter of about $0.35 \mathrm{~mm}$. The beach is highly dynamic and displays rhythmic longshore bar patterns frequently being modified by the formation of rips channels. The wave (significant wave height, peak wave period and direction) and tide characteristics were obtained from numerical modelling. We used SLR predictions until 2100 for the specific area.

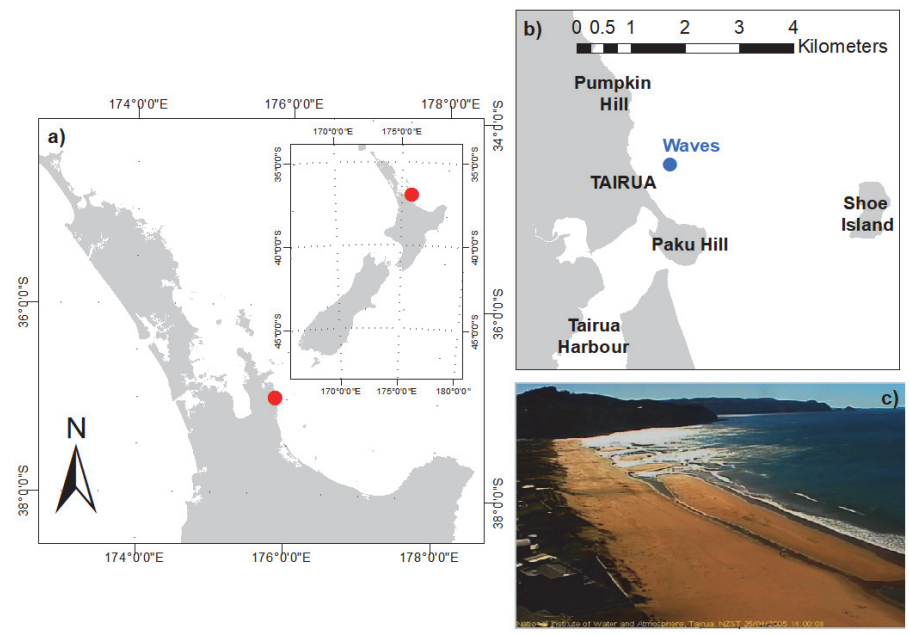

Fig. 2. a) and b) Tairua beach location c) Camera view of Tairua beach (courtesy of NIWA and Waikato Regional Council).

\section{Methods}

The Participants to the Shorecast were asked to predict shoreline evolution at Tairua beach for the period 2014-2017, by using data to train their models from (1999-2014). For the Shorecast, we only provided the wave characteristics for the period 2014-2017, but not the shoreline evolution. This ensured that participants would not be biased by knowing the "result" and so avoided that the competition was reduced to a parameter fitting/calibration exercise. 


\section{Results}

Overall, 19 models among Equilibrium Model types (12) and Machine Learning techniques (7) were used to predict shoreline behavior. Interestingly, almost all models displayed agreement with the observations, but they also indicated shortcomings that future research will need to address. Fig. 3 shows two examples: a Hybrid model (cyan line) and a Machine Learning model (magenta line). As can be seen in Fig. 3, upper panel, both models are able to capture seasonal to interannual changes in shoreline position. However, the Hybrid model was also able to predict faster shoreline changes. In general, many of the models reproduced the overall mean trend and seasonality but often failed to reproduce these large variations at faster time-scales as those induced by storms. Additionally, models showed a better performance during the hindcast period. In general, predictions followed a smooth trend, showing less variability during the prediction period (Fig. 3, bottom panel). Differences during hindcast and shorecast models performance were more evident for machine learning models than for hybrid models (Fig. 3, bottom panel).
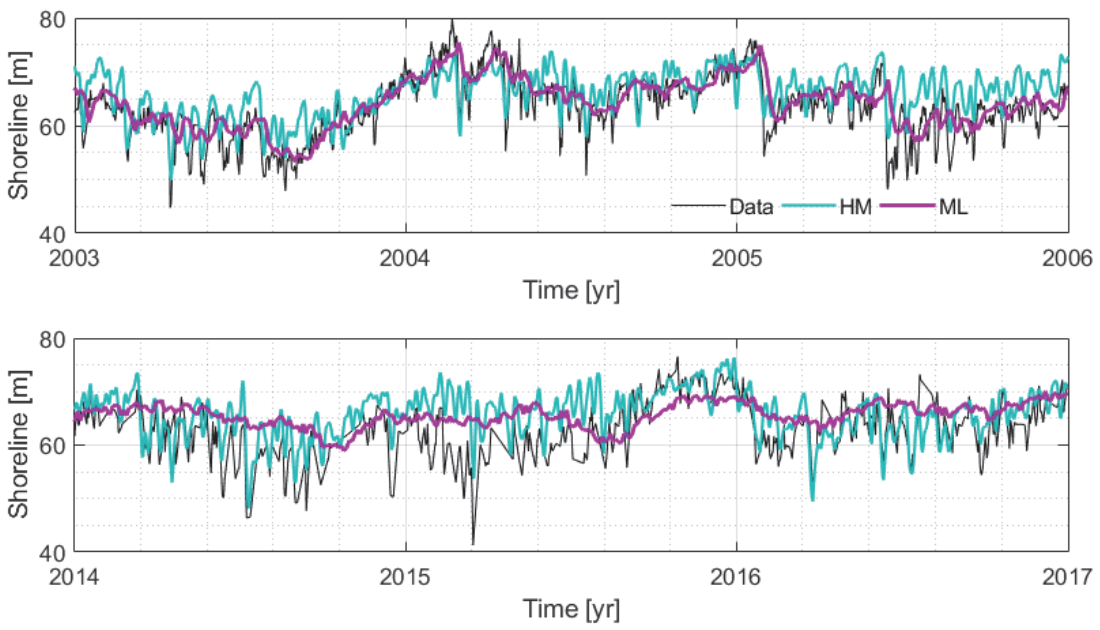

Fig. 3. Top panel: Hindcast prediction from 2003 - 2006. Bottom panel: Shorecast prediction. Example of a Hybrid model (cyan) and of Machine learning model (magenta). The black line indicates the observed shoreline position.

\section{Conclusion}

We used observations of shoreline change at Tairua beach (New Zealand) to perform a "blind" test of numerical models. Our objective was to test model performance avoiding the possibility of calibration. Results indicate that both 
modelling methodologies can reproduce shoreline change over the medium term. All participants to the blind test appreciated the value of attempting uncalibrated predictions and it is hopeful that future studies will attempt similar tests.

\section{Acknowledgements}

We wish to thank all people and institutions that have made this research possible by making data available. In particular, we wish to thank the Waikato Regional Council, NIWA, George Payne and B. Blossier for their work in the codes for the video images, R. Bell (NIWA) for the tide and SLR data, and MetOcean for the wave hindcast. Funding from the Auckland Hazard Hub and a project awarded to GC (Climate change impacts on weather-related hazards) are gratefully acknowledged. 